\title{
Nitrate-Nitrogen Sufficiency Ranges in Leaf Petiole Sap of Brassica oleracea L., Pac Choi Grown with Organic and Conventional Fertilizers
}

\author{
May Elfar Altamimi ${ }^{1}$ \\ Department of Horticulture, Forestry, and Recreation Resources, Kansas \\ State University, 2021 Throckmorton, Manhattan, KS, 66506-5506
}

\author{
Rhonda R. Janke \\ Department of Horticulture, Forestry, and Recreation Resources, Kansas \\ State University, 2021 Throckmorton, Manhattan, KS, 66506-5506; and \\ Department of Statistics, Kansas State University, 101 Dickens Hall, \\ Manhattan, KS 66506-5506
}
Kimberly A. Williams
Department of Horticulture, Forestry, and Recreation Resources, Kansas State University, 2021 Throckmorton, Manhattan, KS, 66506-5506

\begin{abstract}
Nathan O. Nelson
Department of Agronomy, Kansas State University, 2004 Throckmorton, Manhattan, KS 66506-5506
\end{abstract}

\section{Leigh W. Murray \\ Department of Statistics, Kansas State University, 101 Dickens Hall, Manhattan, KS 66506-5506}

Additional index words. Brassica oleracea, cardy meter, conventional fertilizer, tissue total nitrogen, root medium, high tunnel, standards, $\mathrm{NO}_{3}-\mathrm{N}$

\begin{abstract}
Greenhouse experiments were conducted to determine the response of Brassica oleracea L., pac choi to fertilizer rates and sources and to establish optimal soluble nitrogen $(\mathrm{N})$ application rates and nitrate meter sufficiency ranges. Conventional soluble fertilizer was formulated from inorganic salts with a 4:1 $\mathrm{NO}_{3}-\mathrm{N}: \mathrm{NH}_{4}-\mathrm{N}$ ratio. Phosphorus $(P)$ was held at $1.72 \mathrm{~mm}$ and potassium $(\mathrm{K})$ at $0.83 \mathrm{~mm}$ for all treatment levels. The organic soluble fertilizer, fish hydrolyzate $(2 \mathrm{~N}-1.72 \mathrm{P}-0.83 \mathrm{~K})$, was diluted to provide the same $\mathbf{N}$ levels as with conventional treatments. Both fertilizers were applied at $\mathrm{N}$ rates of $0,32,75,150,225,300$, and $450 \mathrm{mg} \cdot \mathrm{L}^{-1}$. Seedlings were transplanted and fertilizer application began at 18 days. Plants were harvested at 7 weeks (5 weeks post-transplanting) after receiving 15 fertilizer applications during production. Samples of the most recently matured leaves were harvested weekly and analyzed for petiole sap $\mathrm{NO}_{3}-\mathrm{N}$ and leaf blade total $\mathbf{N}$ concentration. Leaf count, leaf length, and chlorophyll content were also measured weekly. Fresh and dry weights were determined on whole shoots and roots. Optimum yield was achieved at the $150-\mathrm{mg} \cdot \mathrm{L}^{-1}$ fertility rate with both conventional and organic fertilizers. Field and high tunnel experiments were conducted to validate the sufficiency ranges obtained from the greenhouse studies. Sufficiency levels of $\mathrm{NO}_{3}-\mathrm{N}$ for pac choi petiole sap during Weeks 2 to 3 of production were 800 to $1500 \mathrm{mg} \cdot \mathrm{L}^{-1}$ and then dropped to 600 to $1000 \mathrm{mg} \cdot \mathrm{L}^{-1}$ during Weeks 4 through harvest for both conventional and organic fertilizers sources. Total $\mathrm{N}$ in leaf tissue was less responsive to fertilizer rate effects than petiole sap $\mathrm{NO}_{3}-\mathrm{N}$. Chlorophyll content was not useful in evaluating pac choi $\mathrm{N}$ status. These guidelines will provide farmers with information for leaf petiole $\mathrm{sap} \mathrm{NO}_{3}-$ $\mathbf{N}$ to guide in-season $\mathbf{N}$ applications.
\end{abstract}

Research has shown that plant analysis can determine the $\mathrm{N}$ needs of many crops (Gardner, 1989a; Gardner and Pew, 1972). Regular tissue analysis should enable farmers

Received for publication 3 Oct. 2012. Accepted for publication 24 Dec. 2012.

${ }^{1}$ To whom reprint requests should be addressed; e-mailmtamimi@ksu.edu. and to reduce the extra cost with excessive fertilizer has encouraged research on the nitrate test for petiole sap in vegetables. Petiole sap nitrate-nitrogen (PSNN) levels associated with maximum growth rate or yield have been determined for vegetable crops like cabbage (Brassica oleracea L. Capitata group) (Gardner, 1989a; Schulbach et al., 2007); broccoli (Brassica oleracea L. Italica group) (Gardner, 1989b; Hochmuth, 1994); lettuce (Lactuca sativa L.) (Schulbach et al., 2007); and collards (Brassica oleracea L. Acephala group) (Hochmuth, 1994), but not for pac choi. The objectives of this study were to: 1 ) determine if petiole sap tests can be used to identify $\mathrm{N}$ sufficiency in pac choi; 2) determine if fertilization system (organic and inorganic) affects the potential use of petiole sap tests for $\mathrm{N}$ management; and 3 ) evaluate petiole sap response to a fertilization regime in field and high tunnel environments.

\section{Materials and Methods}

A greenhouse experiment with pac choi (Brassica rapa L. Chinensis group 'Mei Qing'; Johnny's Selected Seed, Winslow, ME) was conducted during the fall of 2008 (1 Nov. to $23 \mathrm{Dec}$.) in a glass greenhouse at the Kansas State University Throckmorton Plant Sciences Center, Manhattan, KS. Treatments were arranged in a randomized completeblock factorial design with seven $\mathrm{N}$ rates $\times$ two fertilizer sources (conventional and organic). The number of blocks (replicates) differed between parameters with all measured in six blocks except total leaf $\mathrm{N}$ and PSNN, which were measured as the average of two blocks from each treatment, resulting in three replications.

Pac choi seeds were sown on 1 Nov. in plugs using a superfine germinating mix (Conrad Fafard, Inc., Agawam, MA). Plugs were placed under mist for $18 \mathrm{~d}$, and 84 seedlings were transplanted on 18 Nov. into $14-\mathrm{cm}$ pots $\left(2000 \mathrm{~cm}^{3}\right)$. The plants were grown in a barkbased root media (Sunshine Mix Special Blend E6340; SunGro Horticulture, Bellevue, WA). Nutrient treatments included seven concentrations of $\mathrm{N}(0,32,75,150,225,300$, and $450 \mathrm{mg} \cdot \mathrm{L}^{-1}$ ) from two fertilizer sources (conventional and organic). The conventional soluble fertilizer was formulated from inorganic salts to result in a $4: 1 \mathrm{NO}_{3}-\mathrm{N}: \mathrm{NH}_{4}-\mathrm{N}$ ratio. Constant levels of other nutrients were supplied, except in the control ( $0 \mathrm{~N}$ treatments) (Table 1). The organic soluble fertilizer was fish hydrolysate (Neptune's Harvest, Gloucester, MA) with $2 \mathrm{~N}-1.72 \mathrm{P}-0.83 \mathrm{~K}$ diluted at each application to get the exact $\mathrm{N}$ concentration for different rates (except for the control). This resulted in ranges of 27 to $387 \mathrm{mg} \cdot \mathrm{L}^{-1} \mathrm{P}$ and 13 to $123 \mathrm{mg} \cdot \mathrm{L}^{-1} \mathrm{~K}$ (Table 2). Temperature was monitored using HOBO Environmental Monitors (Onset Computer Corp., Bourne, MA). Air temperature averaged $18.2{ }^{\circ} \mathrm{C}$ during the night and $22.3{ }^{\circ} \mathrm{C}$ during the day. Supplemental light from $400-\mathrm{W}$ highpressure sodium lamps (P.L. Light Systems, 
Table 1. Fertilizer salts (mM) used to formulate conventional fertilizer at different nitrogen $(\mathrm{N})$ fertility rates.

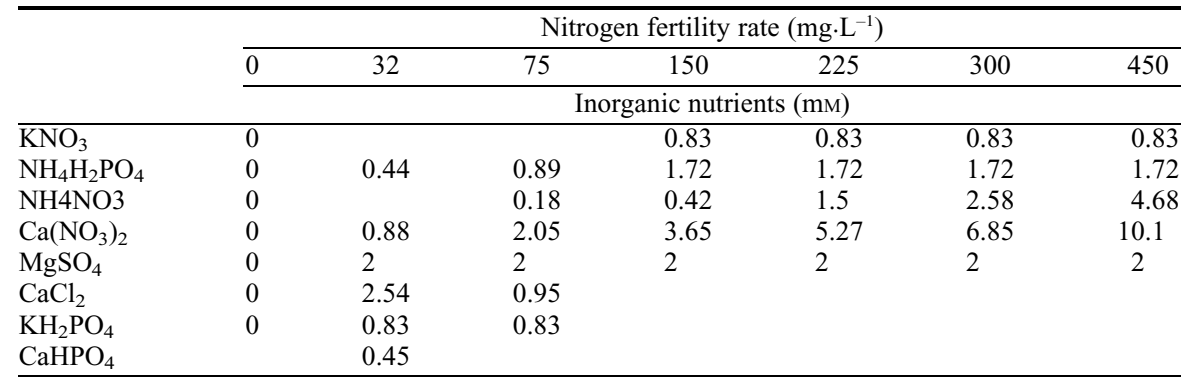

Table 2. Nutrient levels (mM) resulting from fish hydrolyzate dilution to obtain different nitrogen fertility rates.

\begin{tabular}{llllrrrr}
\hline & \multicolumn{7}{c}{ Nitrogen fertility rate $\left(\mathrm{mg} \cdot \mathrm{L}^{-1}\right)$} \\
\cline { 2 - 8 } & 0 & 32 & 75 & \multicolumn{7}{c}{150} & 225 & 300 & 450 \\
\cline { 2 - 8 } & 0 & 2.29 & 5.36 & 10.71 & 16.07 & 21.43 & 32.14 \\
\hline $\mathrm{N}$ & 0 & 1.75 & 4.61 & 9.21 & 13.82 & 18.43 & 27.64 \\
$\mathrm{P}_{2} \mathrm{O}_{5}$ & 0 & 0.94 & 2.2 & 4.39 & 6.59 & 8.79 & 13.18 \\
$\mathrm{~K}_{2} \mathrm{O}$ & 0
\end{tabular}

Beamsville, Ontario, CA) was provided daily for $12 \mathrm{~h}$ from $11 \mathrm{Dec}$. to $23 \mathrm{Dec}$. The water source used for the experiment was municipal water, which had very low alkalinity (39 $\mathrm{mg} \cdot \mathrm{L}^{-1}$ ). Plants were fertigated when gravimetric weight of sentinel pots of each fertilizer treatment decreased by $30 \%$ from container capacity as a result of water loss. We applied a measured volume of fertilizer solution at each watering to result in a controlled leaching fraction of 0.15 . The total number of applications of fertilizer by the end of the growing season was 15 . We used a pour-through method (Cavins et al., 2008) to monitor $\mathrm{pH}$ and electrical conductivity (EC) each time pots were fertilized. After each fertilizer application, we allowed pots to equilibrate for $1 \mathrm{~h}$ and then placed them over plastic saucers. We added distilled water $(75 \mathrm{~mL})$ and collected the leachate. We measured EC and $\mathrm{pH}$ for each sample with an Accumet Excel XL 20 pH/conductivity meter (Fisher Scientific LLC, Denver, CO). After plants were 2 weeks old, we took leaf samples and leaf count weekly. We collected the youngest, fully expanded leaf from each pot and measured for PSNN and total leaf $\mathrm{N}$. We separated blades from the petioles and dried the blades in a forced-air oven at $70{ }^{\circ} \mathrm{C}$ for $72 \mathrm{~h}$ and then ground them in a stainless steel Wiley mill (Scientific Apparatus, Philadelphia, PA) to pass a 20-mesh screen for total $\mathrm{N}$ analysis using a dry combustion procedure (TruSpec CN; LECO Corp., St. Joseph, MO) at the Kansas State University Soil Testing Laboratory, Manhattan, KS (Wright and Bailey, 2001). We chopped the petioles and pressed them with a garlic press to extract plant sap, which we analyzed immediately for $\mathrm{NO}_{3}-\mathrm{N}$ with a handheld ion-specific electrode (Cardy $\mathrm{NO}_{3}^{-}$meter; Horiba, Ltd., Kyoto, Japan) (Hochmuth, 1994). We calibrated the meter before analysis and after every 10 measurements with a standard of $2000 \mathrm{mg} \cdot \mathrm{L}^{-1} \mathrm{NO}_{3}$ and adjusted the slope with a $150 \mathrm{mg} \cdot \mathrm{L}^{-1} \mathrm{NO}_{3}$ solution. We placed a few drops of the petiole sap on a sampling sheet and recorded the reading after the value stabilized. Meter readings were in units of $\mathrm{mg} \cdot \mathrm{L}^{-1}$ $\mathrm{NO}_{3}$ and were converted to $\mathrm{NO}_{3}-\mathrm{N}$ (Hartz et al., 2007).

We recorded plant chlorophyll content weekly with a chlorophyll meter (SPAD-502; Spectrum Technologies, Inc., Plainfield, IL) by taking the average reading of three leaves located on the second whorl per pot. We also measured leaf length weekly and recorded shoot fresh and dry weights (dried for a minimum of $48 \mathrm{~h}$ at $70^{\circ} \mathrm{C}$ in a forced-air oven) at the end of the experiment. Data were analyzed using the SAS MIXED procedure (SAS Version 9.1.3, Cary, NC). F-tests and least square means with SES were calculated for the fixed effects of fertility source, $\mathrm{N}$ rate, and their interaction. In addition, contrasts were used to test the equality of means for pairs of adjacent $\mathrm{N}$ rates (i.e., $\mathrm{N}$ rates 0 vs. 32,32 vs. 75 , etc.). Optimum yield was determined to be the point at which no significant differences were present between that point and the next higher nutrient level. We calculated nutrient sufficiency ranges at the $95 \%$ confidence interval of PSNN at the optimum nutrient level. We performed regression analysis between the PSNN and total leaf $\mathrm{N}$ and calculated regression equations for individual sampling dates.

A field experiment was conducted with pac choi (Brassica rapa L. Chinensis group 'Mei Qing;' Johnny's Selected Seed) in Fall 2008 (5 Sept. to 18 Oct.) at the Kansas State University Horticulture Research Center (Olathe, KS) on a Kennebec silt loam. Separate, adjacent trials were performed in two systems: open-field plots and high tunnel plots. High tunnel plots had 1.5-m sidewalls (Stuppy, North Kansas City, MO) and were covered with single-layer 6-mil $(0.153 \mathrm{~mm}) \mathrm{K}$-polyethylene (Klerk's Plastic Product Manufacturing, Inc., Richburg, SC). Each system contained: six $\left(3 \times 3.2 \mathrm{~m}^{2}\right)$ plots, which had been established in 2002 and arranged in a randomized complete block design with three replications. The treatment factor at establishment was fertilizer source with one plot per replication being managed with organic amendments and the other with conventional amendments (Knewtson, 2008). Organic plots were managed in compliance with USDA National Organic Program standards and were inspected and certified in 2003, 2006, 2007, and 2008. For this study, beginning in 2007, each high tunnel or field plot was subdivided into three $3.2 \times 6.1-\mathrm{m}$ subplots, to which one of three fertilizer levels were assigned (control, low, and high). We determined fertilizer rates based on soil analysis at the beginning of the study in 2007 and recommendations for vegetable crops in Kansas (Marr et al., 1998). The overall experimental design in 2008 for each system was therefore a randomized complete block design with a split plot. Fertilizer source (conventional vs. organic) was the whole-plot treatment factor and fertilizer level was the split-plot treatment factor.

All plots were planted to a buckwheat cover crop (Fagopyrum sagittatum Gilib.) during the summer before the experiment started. Control plots received no supplemental fertilizer. The low treatments received preplant fertilizer amendment applied one time per year (in the spring). Compost application rates were based on the assumption that $50 \%$ of the $\mathrm{N}$ from compost would be available to plants during the growing season, whereas $100 \%$ would be available from conventional fertilizers (Warman and Havard, 1997). We applied Jack's Peat-Lite 20N-4.4P-16.6K (J. R. Peters, Inc., Allentown, MO) at a rate of $87 \mathrm{lb} \mathrm{N} / \mathrm{ha}$ for conventional plots and a mixedsource compost (Microleverage $0.6 \mathrm{~N}-0.4 \mathrm{P}$ $4.4 \mathrm{~K}$, Hughesville, MO) at a rate of $176 \mathrm{lb} \mathrm{N} / \mathrm{ha}$ for organic plots. Starting 2 weeks after planting, high-fertility treatments plots received additional soluble fertilizer at a rate of $7.24 \mathrm{~kg} \cdot \mathrm{ha}^{-1}$ applied three times (9 Sept., 18 Sept., and 28 Sept.) during the growing season. Organic plots received fish hydrolyzate $2 . \mathrm{N}-1.72 \mathrm{P}-0.83 \mathrm{~K}$ (Neptune's Harvest, Gloucester, MA). The conventional plots received $21.6 \mathrm{~g} / 20-\mathrm{ft}^{2}$ plot $\mathrm{KNO}_{3}$ and $6.24 \mathrm{~g} / 20-\mathrm{ft}^{2}$ plot $\mathrm{Ca}\left(\mathrm{NO}_{3}\right)_{2}$, a rate calculated to apply an amount of $\mathrm{N}$ and calcium equivalent to that present in the fish hydrolyzate (TalaveraBianchi, 2009).

We started pac choi seeds in a greenhouse (8 Aug.) in $13 \times 26$-in. flats using commercial media (Sunshine Mix Special blend E6340; SunGro Horticulture, Bellevue, WA) supplemented with MicroLeverage compost until plants were transplanted on 5 Sept. to high tunnel and field plots $(3 \times 3.2 \mathrm{~m})$. Each plot had 20 plants/row, two plants across the row, for the inner two rows and 20 plants per row, and one plant across the row for the outer border. We collected plant samples from the center of the two inner rows, avoiding the plants on the outer edges of each plot. We chose sampled plants using a random number generator. 
When plants were 2 weeks old, we took leaf samples weekly. We sampled three plants from each fertility source $\times$ fertilizer level subplot on 20 Sept., 27 Sept., 6 Oct., and 11 Oct. by collecting the youngest fully expanded leaf from each plant. We measured PSNN, total leaf $\mathrm{N}$, and $\mathrm{K}$ levels following the same procedure as the greenhouse study and recorded shoot fresh weight and dry weight at the end of the experiment.

Data were analyzed using the SAS MIXED procedure, SAS Version 9.3.1 (Cary, NC). Field plot data and high tunnel data were analyzed separately. For each system, the mixed model included the following effects: replication, fertilizer source, replication $\times$ fertilizer source (the whole plot error term), fertilizer source $\times$ fertilizer level interaction, and an extra effect was considered random. Statistical calculations were similar to those for the analysis of the greenhouse experiment.

\section{Results and Discussion}

In the greenhouse experiment, conventional treatment yielded greater fresh and dry weights at 75,150 , and $450 \mathrm{mg} \cdot \mathrm{L}^{-1} \mathrm{~N}$ rates compared with organic treatments (Fig. 1AB). The maximum fresh yield for both organic $(31.0 \mathrm{~g} /$ plant $)$ and conventional (40.0 g/plant) was obtained at the $\mathrm{N}$ rate of $150 \mathrm{mg} \cdot \mathrm{L}^{-1}$. Root dry weight showed no differences between $\mathrm{N}$ rates $(32,75,150,225,300$, and 450) (Fig. 2), but it varied more than aboveground dry matter. Significant $\mathrm{N}$ rate and fertilizer source interaction is the result of significant differences between conventional and organic with the $225-\mathrm{mg} \cdot \mathrm{L}^{-1} \mathrm{~N}$ rate, where the weight of the root system was significantly greater for organic than conventional treatment except at the $450-\mathrm{mg} \cdot \mathrm{L}^{-1} \mathrm{~N}$ rate. Leaf count measurements at harvest were consistent with fresh and dry weight for both conventional and organic treatments (Fig. 3A) with a significantly higher number of leaves at the $450 \mathrm{mg} \cdot \mathrm{L}^{-1} \mathrm{~N}$ rate in conventional vs. organic. Although leaf length between 75 and $150 \mathrm{mg} \cdot \mathrm{L}^{-1}$ did not increase significantly (Fig. 3B), leaf count and final yield were higher at the $150-\mathrm{mg} \cdot \mathrm{L}^{-1} \mathrm{~N}$ rate. Although the SPAD meter chlorophyll content has been used effectively in detecting $\mathrm{N}$ deficiency in some crops like cabbage and carrots (Westerveld et al., 2004), it was not a good diagnostic tool for evaluating pac choi $\mathrm{N}$ status. We found no significant differences among $\mathrm{N}$ rates throughout the growing period for this parameter in the greenhouse experiment (Fig. 4).

The significant decline in pac choi fresh and dry weight in the conventional treatment beyond $150 \mathrm{mg} \cdot \mathrm{L}^{-1} \mathrm{~N}$ and in the organic treatment beyond $300 \mathrm{mg} \cdot \mathrm{L}^{-1} \mathrm{~N}$ could be explained by the significant increase in $\mathrm{EC}$ in the root media, because more concentrated fertilizer was applied in both organic and conventional treatments (Fig. 5). Literature for similar crops has shown that lettuce had a $10 \%$ yield reduction with a $1.4 \mathrm{dS} \cdot \mathrm{cm}^{-1} \mathrm{EC}$ level in the root media (Evans, 2006). Scuderi et al. (2009) showed that using nutrient
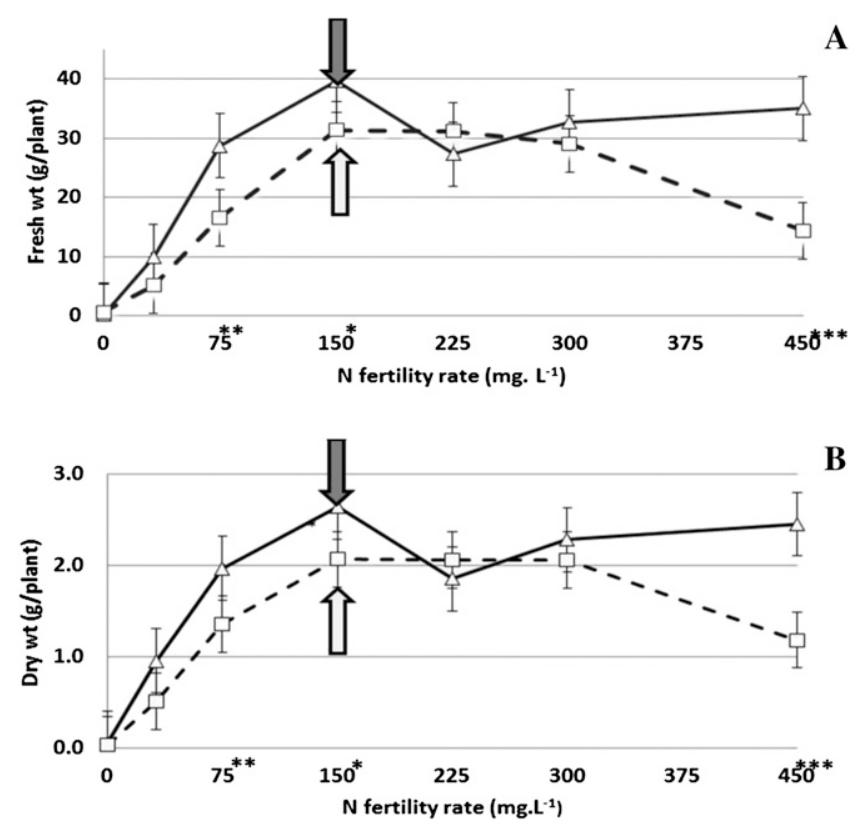

Fig. 1. Pac choi fresh (A) and dry (B) weight (g/plant) at harvest for the greenhouse study at different nitrogen $(\mathrm{N})$ fertility levels for conventional $(\triangle)$ and organic $(\square)$ treatments. Arrows show the point at which there were no significant differences between $\mathrm{N}$ fertility rate and the next higher nutrient level for conv $\downarrow$ and org $\uparrow$ treatments. $*$, **, and ***Significant differences between conv and org at $\alpha=0.05,0.01$, and 0.001 , respectively.

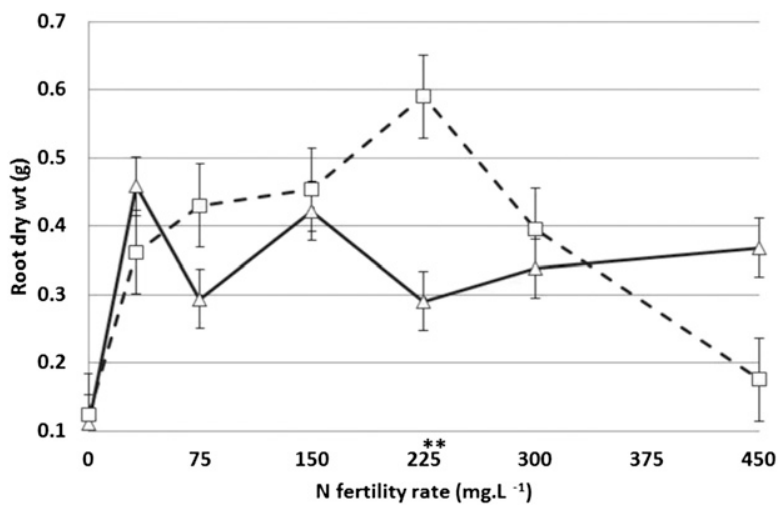

Fig. 2. Pac choi root dry weight (g/plant) for greenhouse study at harvest for conventional $(\triangle)$ and organic ( $\square$ ) treatments. $* * *$ Significant differences between conv and org at $\alpha=0.001$.

solutions with an EC up to $3.6 \mathrm{dS} \cdot \mathrm{cm}^{-1}$. In addition to $\mathrm{EC}$, the end of the experiment media analysis showed a higher level of $\mathrm{NH}_{4}$ in the high rate organic treatments compared with conventional (Elfar Altamimi, 2010). This is probably why the fresh weight and the dry weight decreased more in organic despite both having increased EC levels.

Root medium $\mathrm{pH}$ for the greenhouse study stayed within the acceptable range of 5.5 to 7.0 (Albright, 2010), although it declined as $\mathrm{N}$ rates increased for both organic and conventional treatments but there were no significant differences (Fig. 6). PSNN concentrations, as determined by the nitrate meter, resulted in similar trends for both conventional and organic treatments (Fig. 7). The nitrate concentration in sap derived from the petiole of pac choi leaves increased significantly with increasing $\mathrm{N}$ rate up to $225 \mathrm{mg} \cdot \mathrm{L}^{-1}$ in Week 2 and was either $150 \mathrm{mg} \cdot \mathrm{L}^{-1}$ or $225 \mathrm{mg} \cdot \mathrm{L}^{-1}$ in Weeks 3,4 , and 5. At the maximum yield of $150-\mathrm{mg} \cdot \mathrm{L}^{-1} \mathrm{~N}$ rate, conventional petiole sap $\mathrm{N}$ was greater than organic only in Week 5. PSNN sufficiency concentrations were in the range of 1500 to $2000 \mathrm{mg} \cdot \mathrm{L}^{-1}$ at Weeks 2 and 3 (Fig. 7A-B) and in the range of 1000 to $1500 \mathrm{mg} \cdot \mathrm{L}^{-1}$ from Week 4 until harvest (Fig. 7C-D).

Total $\mathrm{N}$ in leaf tissue in the organic treatments increased significantly with an increasing rate of $\mathrm{N}$ up to $32 \mathrm{mg} \cdot \mathrm{L}^{-1}$ at Week 2 , $75 \mathrm{mg} \cdot \mathrm{L}^{-1}$ at Week 3, $150 \mathrm{mg} \cdot \mathrm{L}^{-1}$ at Week 4, and $225 \mathrm{mg} \cdot \mathrm{L}^{-1}$ at harvest (Fig. 8). The significant increase in total leaf $\mathrm{N}$ for the conventional treatments was up to $32 \mathrm{mg} \cdot \mathrm{L}^{-1}$ at Weeks 2 and 3 and up to $75 \mathrm{mg} \cdot \mathrm{L}^{-1}$ at Weeks 4 and 5 . 

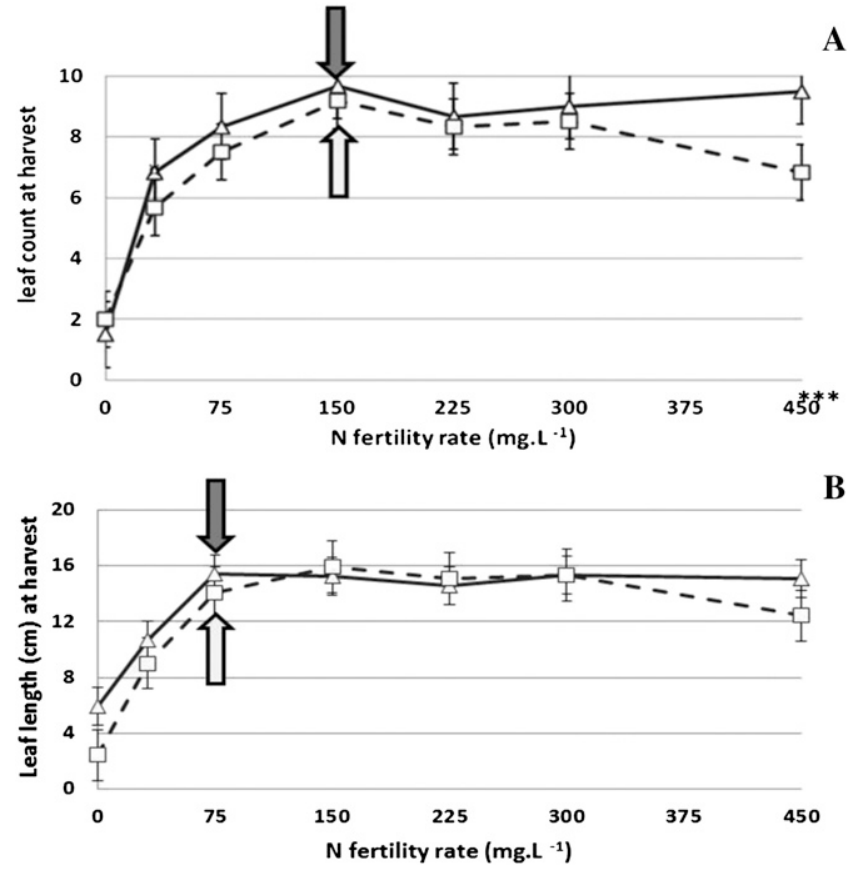

B

Fig. 3. Pac choi count of leaf (A) and leaf length $(\mathrm{cm})(\mathbf{B})$ at harvest for the greenhouse study at different fertility levels for conventional $(\triangle)$ and organic $(\square)$ treatments. Arrows show the point at which there were no significant differences between nitrogen $(\mathrm{N})$ fertility rate and the next higher nutrient level for conv $\downarrow$ and org $\uparrow$ treatments. ${ }^{* * *}$ Significant differences between conv and org at $\alpha=0.001$

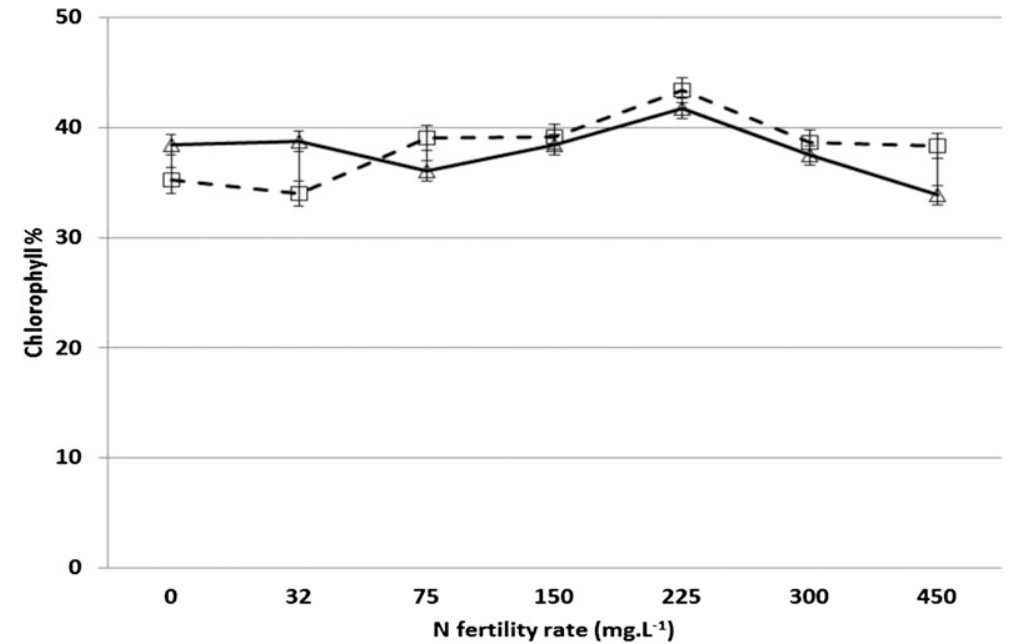

Fig. 4. Pac choi chlorophyll percent at harvest in greenhouse study at different fertility levels for conventional $(\triangle)$ and organic $(\square)$ treatments. No significant differences among nitrogen $(N)$ fertility rates or conv. vs. org treatments.

Although total leaf $\mathrm{N}$ concentration did not correspond to optimal yield, it correlated highly with PSNN concentrations (Fig. 9). The linear relationship between PSNN and total $\mathrm{N}$ measurements indicated that $\mathrm{N}$ management criteria based on dry tissue total $\mathrm{N}$ can be readily converted to criteria based on PSNN, enabling adoption of the nitrate meter as a tool for managing $\mathrm{N}$ in pac choi. Dry tissue total leaf $\mathrm{N}$ can be converted to PSNN readings using the regression equation given. Equations were calculated for Week 3 when supplemental fertilizer might be needed and could still be applied.

In the field study, we saw a highly significant fertility effect occurred for fresh weight at Weeks 3, 4, and 5 at harvest because the maximum yield was obtained with the high $\mathrm{N}$ fertility rate (Fig. 10; Table 3). We also observed a significant fertilizer source effect for fresh weight at harvest for Weeks 3, 4, and 5 in pac choi field plots because organic treatments had higher yield than conventional. For the high tunnel plots, we recorded a significant fertility level effect on fresh weight in Weeks 3, 4, and 5 (Fig. 11) as well as fertilizer source $\times$ fertility interaction in Week 5. The fertilizer source effect was significant only at Week 4 with organic plot yields higher than conventional. Dry weight for field and high tunnel plots, for both organic and conventional treatments, followed the same trend as the fresh weight but was significant only in Weeks 2 and 5 (Table 3).

Sufficiency petiole sap $\mathrm{NO}_{3}-\mathrm{N}$ range $\mathrm{PSNN}$ concentrations were consistent with the greenhouse study results. The organic and conventional treatments showed similar trends for PSNN concentration during the growing season. Field organic sufficiency ranges were 800 to $1200 \mathrm{mg} \cdot \mathrm{L}^{-1}$ at Weeks 2 and 3 and then levels dropped as the plants grew and ranged from 600 to $800 \mathrm{mg} \cdot \mathrm{L}^{-1}$ at Weeks 4 and 5 (Fig. 12A). For field conventional treatments, sufficiency ranges were from 800 to $1000 \mathrm{mg} \cdot \mathrm{L}^{-1}$ at Weeks 2 and 3 and then dropped to 500 to $700 \mathrm{mg} \cdot \mathrm{L}^{-1}$ at Weeks 4 and 5 (Fig. 12B). For high tunnel organic treatments, sufficiency ranges were from 800 to $1000 \mathrm{mg} \cdot \mathrm{L}^{-1}$ for Weeks 2 and 3 and then dropped to 500 to $700 \mathrm{mg} \cdot \mathrm{L}^{-1}$ at Weeks 4 and 5 (Fig. 13A). For high tunnel conventional treatments, sufficiency ranges were 900 to $1100 \mathrm{mg} \cdot \mathrm{L}^{-1}$ at Weeks 2 and 3 and then dropped to 500 to $700 \mathrm{mg} \cdot \mathrm{L}^{-1}$ at Weeks 4 and 5 (Fig. 13B). A significant system effect occurred at Week 4 for total leaf $\mathrm{N}$, a fertility level effect occurred at Week 3 for field plots, and a fertility source effect occurred at Week 3 for high tunnel plots (Table 3).

Sufficiency ranges of PSNN in the greenhouse study followed the same trend as the high tunnel and field studies although they had different values. Sufficiency ranges gleaned from the literature for similar vegetable crops are presented in Table 4. Differences in sufficiency ranges of PSNN among the greenhouse studies compared with high tunnel and field studies could be a result of many factors: 1) low light levels during the growing period were associated with $\mathrm{NO}_{3}-\mathrm{N}$ accumulation. Parks et al. (2008) reported that a reduction of light level was associated with reduced nitrate reductase activity and increased nitrate accumulation in lettuce and spinach. Proietti et al. (2004) showed that spinach grown at a light intensity of $200 \mu \mathrm{mol} \cdot \mathrm{m}^{-2} \cdot \mathrm{s}^{-1}$ had a higher nitrate concentration than those plants grown at 800 $\left.\mu \mathrm{mol} \cdot \mathrm{m}^{-2} \cdot \mathrm{s}^{-1} ; 2\right)$ a short photoperiod also has been reported to increase nitrate accumulation (Cantliffe, 1972). Nitrate is translocated to the leaves, where it is reduced and incorporated into proteins and has an essential role in photosynthesis as a component of chlorophyll. Reduced irradiance has been associated with reduced photosynthetic rates and growth; 3) leafy vegetables grown in a protected environment might contain higher $\mathrm{NO}_{3}-\mathrm{N}$ levels, Lyons et al. (1994) reported that hydroponic-grown head lettuce contains twice the $\mathrm{NO}_{3}-\mathrm{N}$ concentration of field-grown lettuce, although the $\mathrm{N}$ form in the fertilizers was not specified; the 


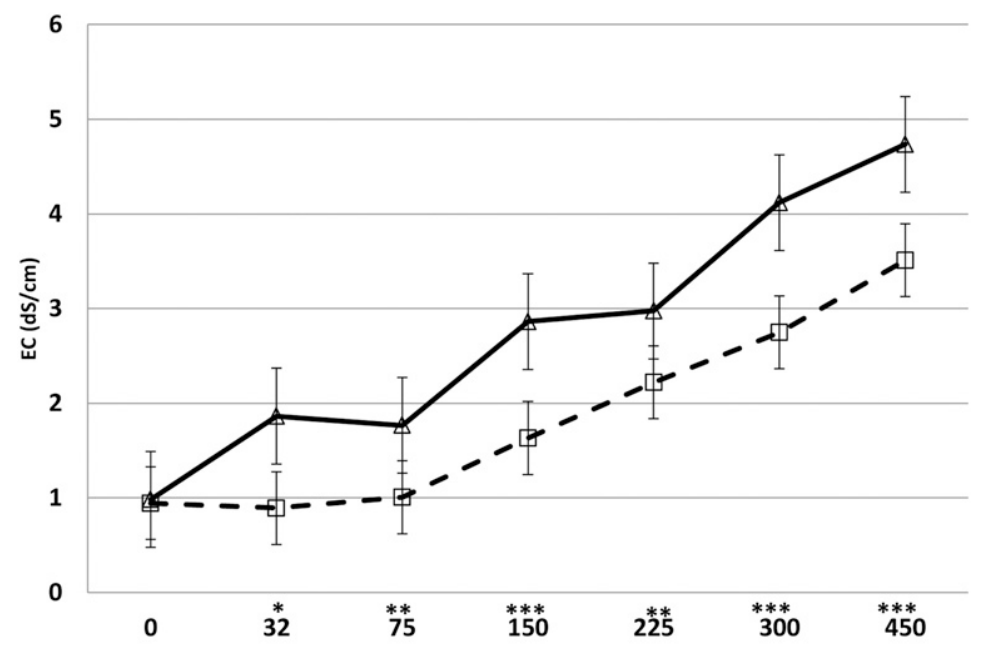

$\mathrm{N}$ fertility rate $\left(\mathrm{mg} \cdot \mathrm{L}^{-1}\right)$

Fig. 5. Pac choi electrical conductivity (EC) $\left(\mathrm{mS} \cdot \mathrm{cm}^{-1}\right)$ measured on saturated media extract at harvest for the greenhouse study for conventional $(\triangle)$ and organic $(\square)$ treatments. ${ }^{*}, *$, and $* * *$ significant differences between conv and org at $\alpha=0.05,0.01$, and 0.001 , respectively.

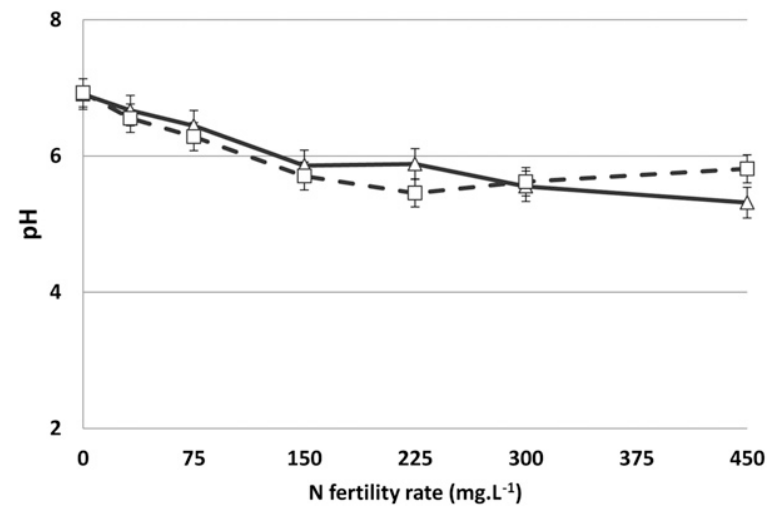

Fig. 6. Pac choi pH measured on saturated media extract at harvest for the greenhouse study for conventional $(\triangle)$ and organic $(\square)$ treatments. No significant differences among nitrogen $(\mathrm{N})$ fertility levels.

previous two factors could be responsible for what Lyons et al. (1994) observed. These factors could result in $\mathrm{NO}_{3}-\mathrm{N}$ accumulation in pac choi leaves in a greenhouse environment.

As listed, there are several environmental factors that could influence the PSNN concentration that corresponds to the optimum $\mathrm{N}$ rate. However, these factors do not preclude the application of PSNN tests as a $\mathrm{N}$ management tool in pac choi. As shown in Figure 7, pac choi PSNN concentrations have a linear plateau or quadratic plateau response to increasing $\mathrm{N}$ application. Furthermore, the PSNN concentration of pac choi at the optimal $\mathrm{N}$ rate is the same as the plateau PSNN concentration, or in other words, the PSNN plateau occurred at the optimum $\mathrm{N}$ rate in the data presented in this study. Therefore, a grower could determine the critical PSNN concentration for a specific environment by simply applying excessive $\mathrm{N}$ to a small group of pac choi (i.e., reference plants). During the growing season, the PSNN of the bulk pac choi could be compared with the PSNN of the reference plants to determine if the $\mathrm{N}$ concentration is adequate. If the PSNN of the bulk pac choi drops below the PSNN of the reference plants, the grower would know to increase the $\mathrm{N}$ supply to avoid yield loss.

This reference plot design would be an efficient, low-cost method for producers to verify that their $\mathrm{N}$ fertilization is adequate. Producers may also be able to decrease $\mathrm{N}$ rates knowing that they would have a system for early detection of $\mathrm{N}$ stress. However, additional research is required to verify the effects of early-season $\mathrm{N}$ stress on pac choi yield and quality.

In summary, PSNN testing gave results that correlated with the laboratory method of total leaf N. In our studies, PSNN sufficiency ranges established in the greenhouse study have the same trend with the sufficiency ranges in field and high tunnel studies. PSNN associated with maximum yield in the field study ranged between 800 and $1200 \mathrm{mg} \cdot \mathrm{L}^{-1}$ at Weeks 2 and 3 and then dropped to 500 to $800 \mathrm{mg} \cdot \mathrm{L}^{-1}$ at Weeks 4 through harvest. Organic and conventional fertilizers resulted in similar ranges, so growers could use these results regardless of their fertilizer source.

We concluded that: 1) PSNN can be used to determine if pac choi $\mathrm{N}$ fertilization is sufficient to achieve optimum yield; 2) fertilization system (organic and inorganic) has no effect on the potential use of petiole sap tests for $\mathrm{N}$ management; and 3) petiole sap response to $\mathrm{N}$ fertilization in field and high tunnel environments follows the same trend as the greenhouse but with lower sufficiency ranges. 


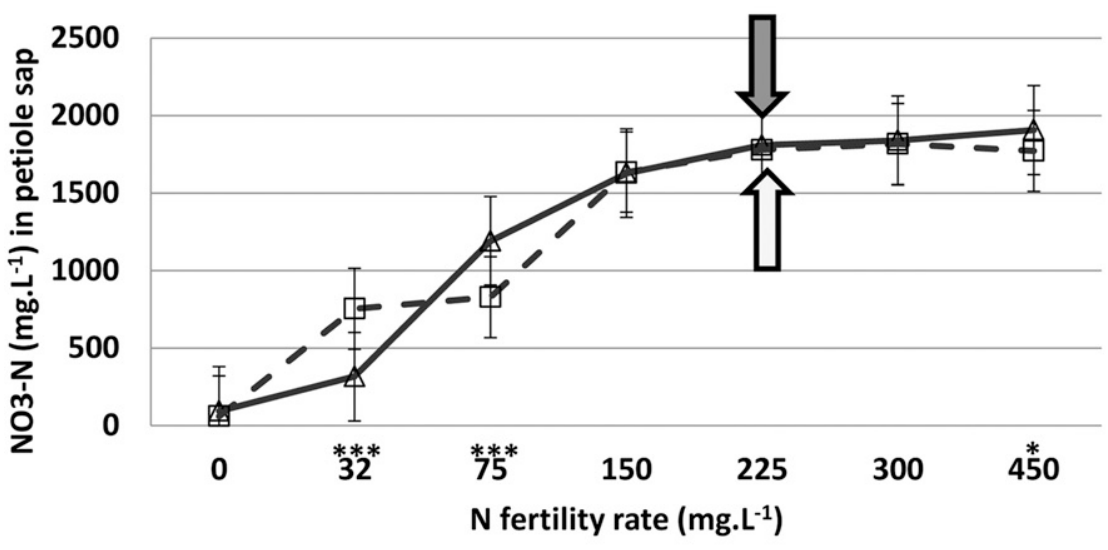

A

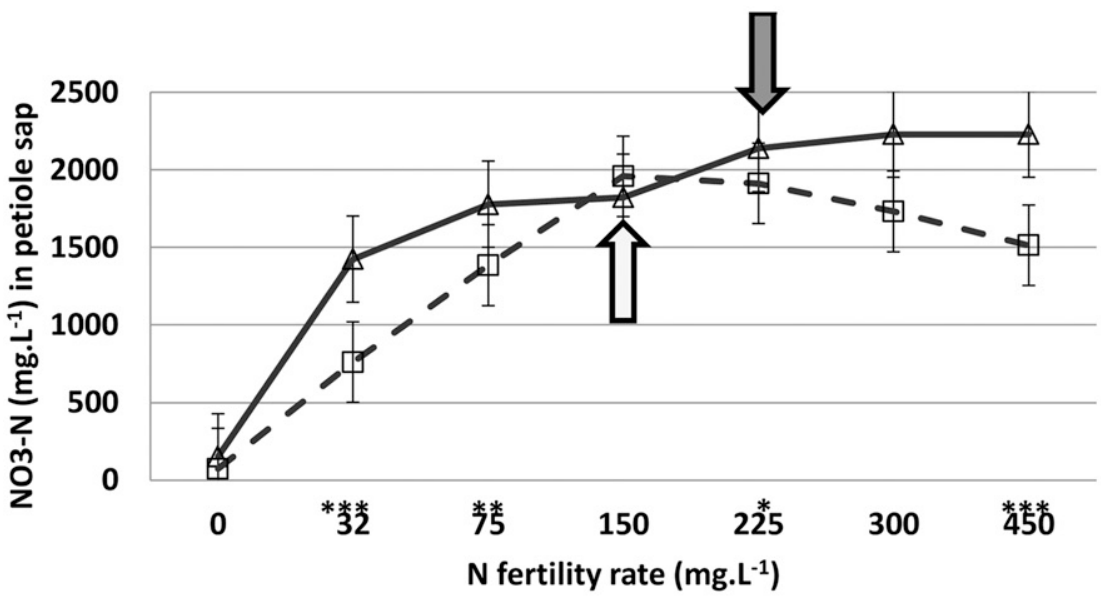

B

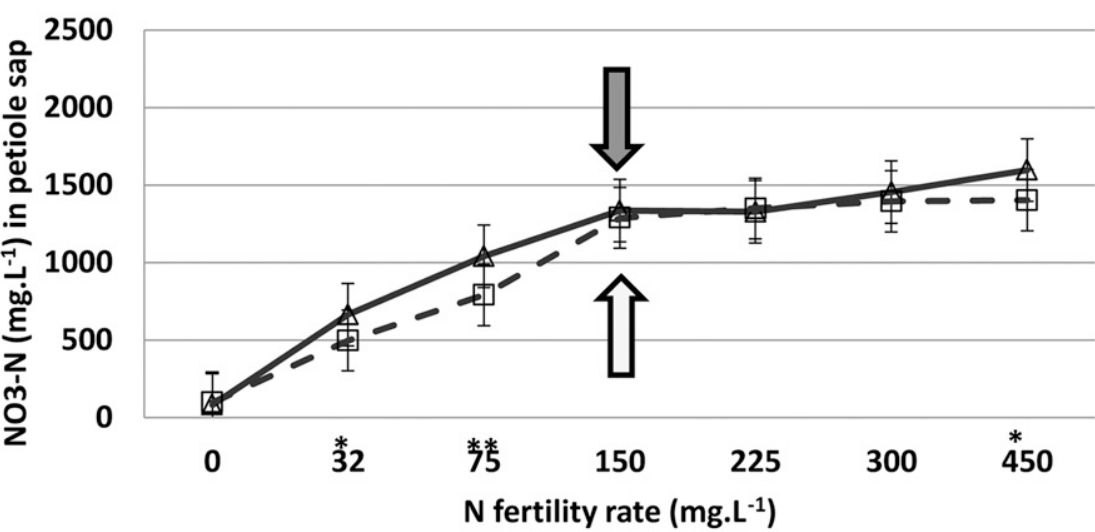

C

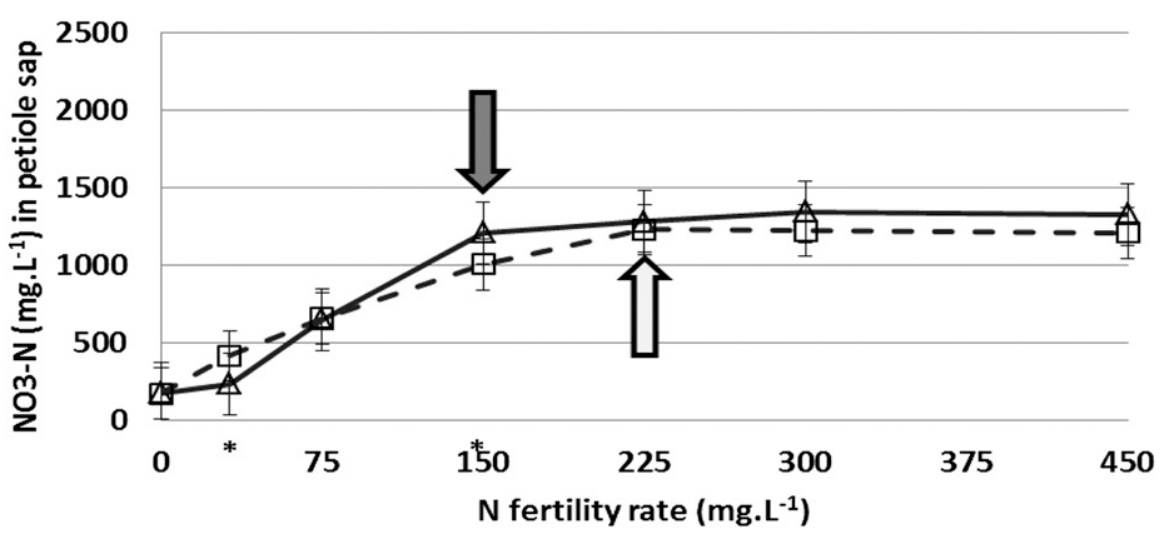

D

Fig. 7. Pac choi petiole sap nitrate-nitrogen levels $\left(\mathrm{mg} \cdot \mathrm{L}^{-1}\right)$ in the greenhouse study for conventional $(\triangle)$ and organic $(\square)$ treatments at Week $2(\mathbf{A})$, Week 3 (B), Week $4(\mathbf{C})$, and Week 5 (D). Arrows show the point at which there were no significant differences between nitrogen $(\mathrm{N})$ fertility rate and the next higher nutrient level for conv and org. 

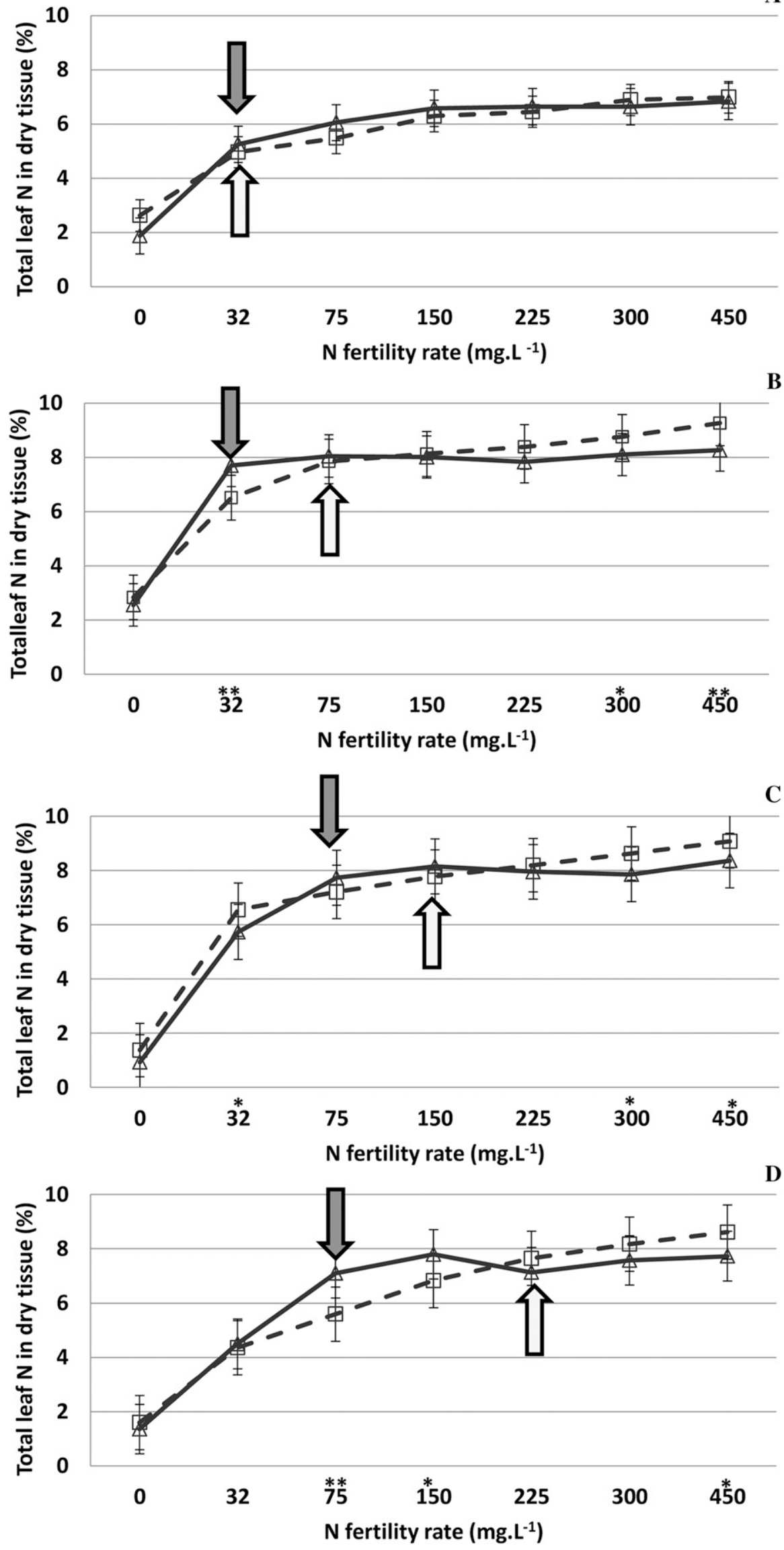

Fig. 8. Total nitrogen $(N)$ percent in pac choi leaves in the greenhouse study for conventional $(\triangle)$ and organic $(\square)$ treatments at Week 2 (A), Week 3 (B), Week 4 (C), and Week 5 (D). Arrows show the point at which there were no significant differences between $\mathrm{N}$ fertility rate and the next higher nutrient level for conv and org. *,*, and ***significant differences between conv and org at $\alpha=0.05,0.01$, and 0.001 , respectively. 


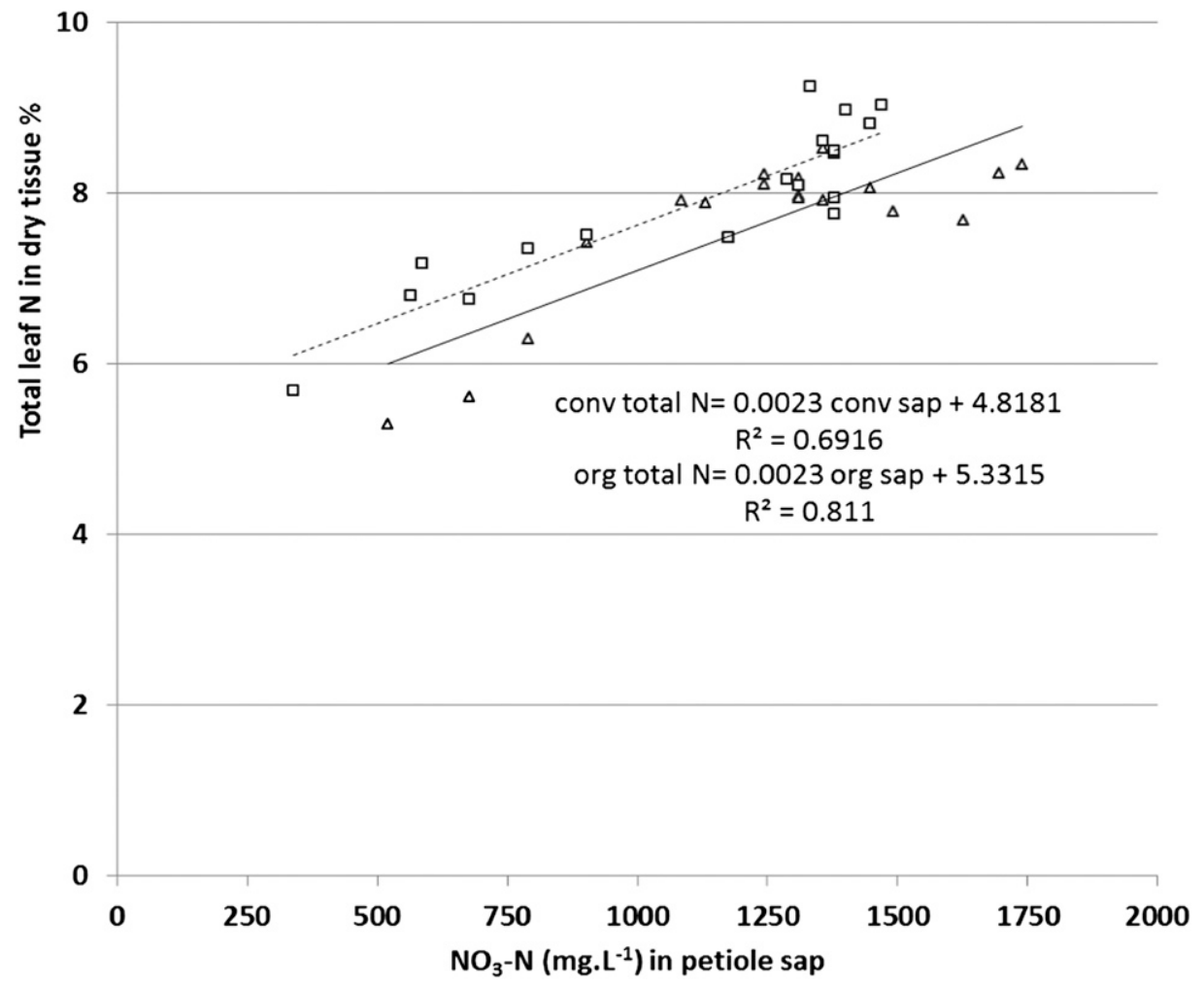

Fig. 9. Linear relationship between total leaf nitrogen $(\mathrm{N})$ percent and petiole sap nitrate-nitrogen (PSNN) (mg. $\left.\mathrm{L}^{-1}\right)$ and the regression equations for the greenhouse study [conventional $(\triangle)$ and organic $(\square)$ ] treatments calculated at Week 3 .

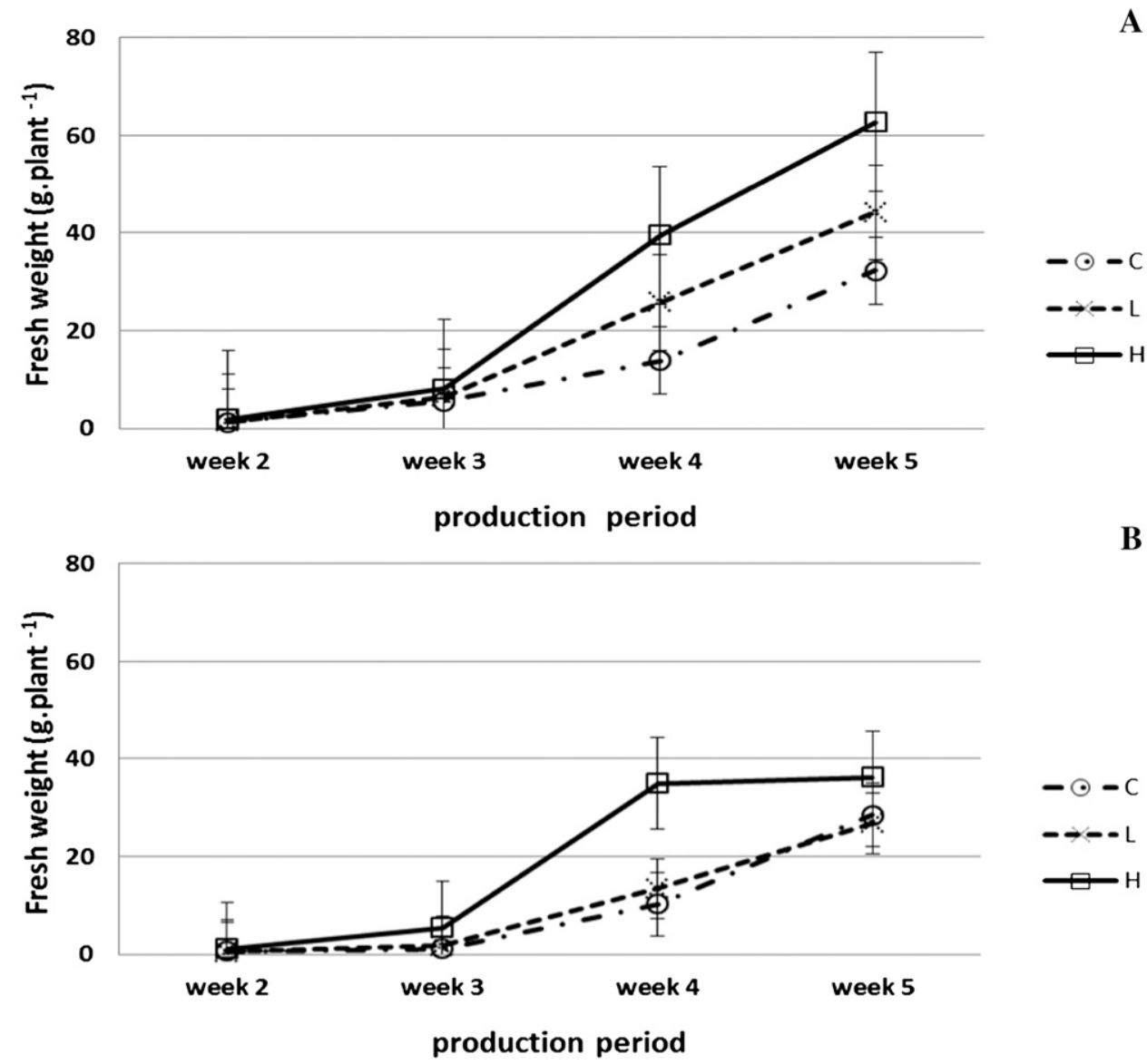

Fig. 10. Pac choi fresh weight (g/ plant) during the production period at field organic (A) and conventional (B) plots for different nitrogen (N) fertility rate (control, low, and high) treatments. 


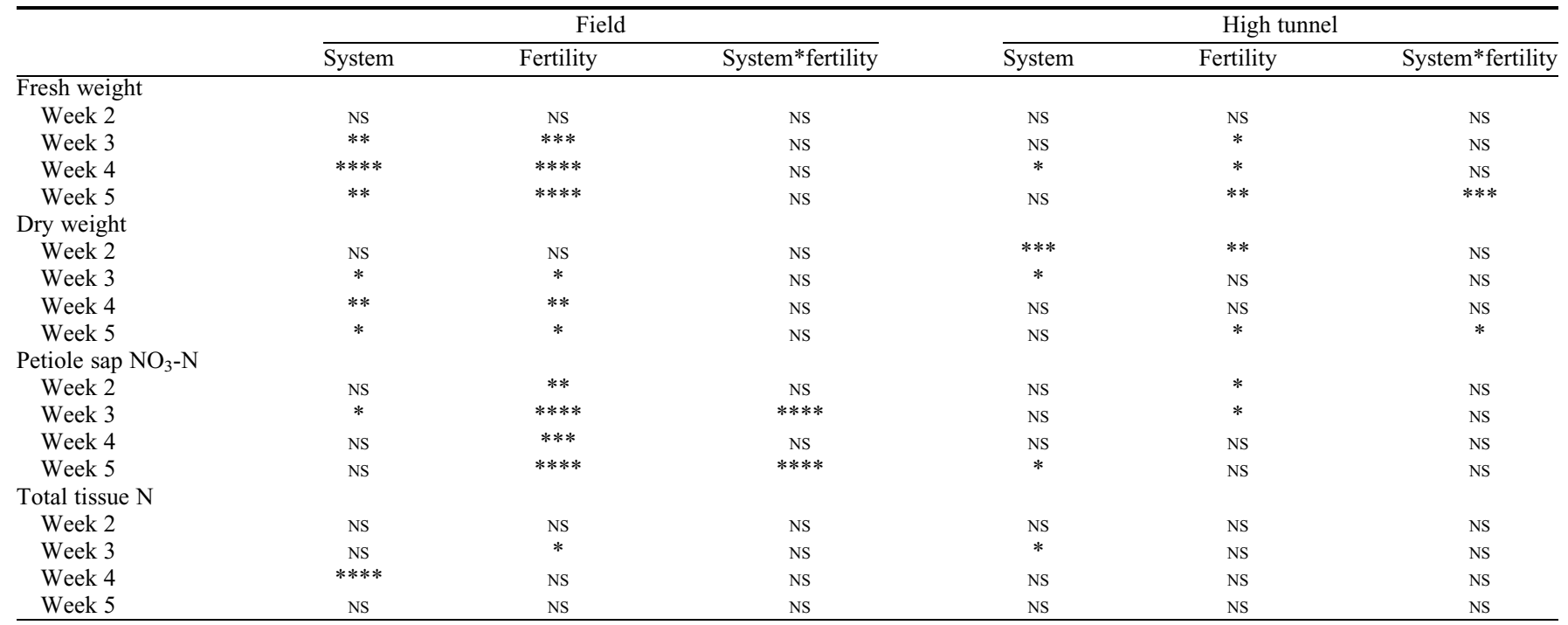

Ns, ${ }^{*}, * *, * * *, * * * *$ Nonsignificant or significant at $\alpha=0.05,0.01,0.001$, and 0.0001, respectively.

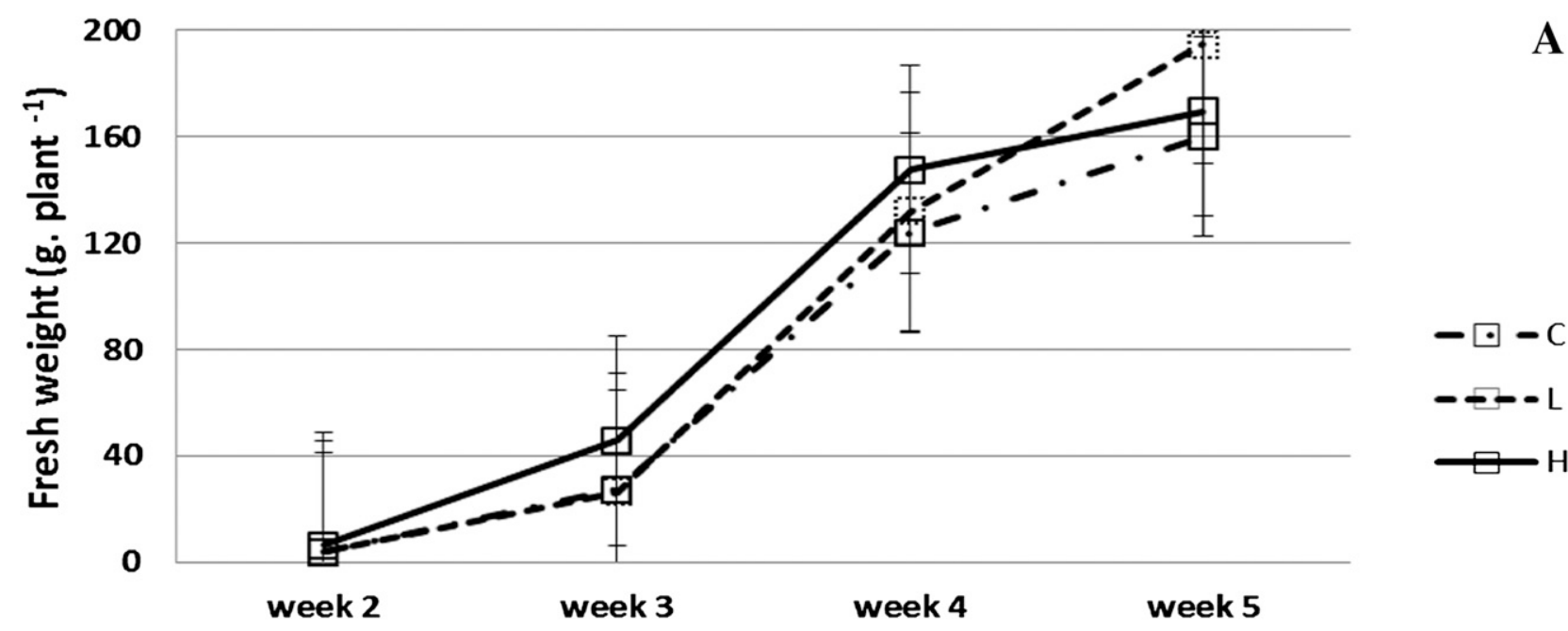

production period

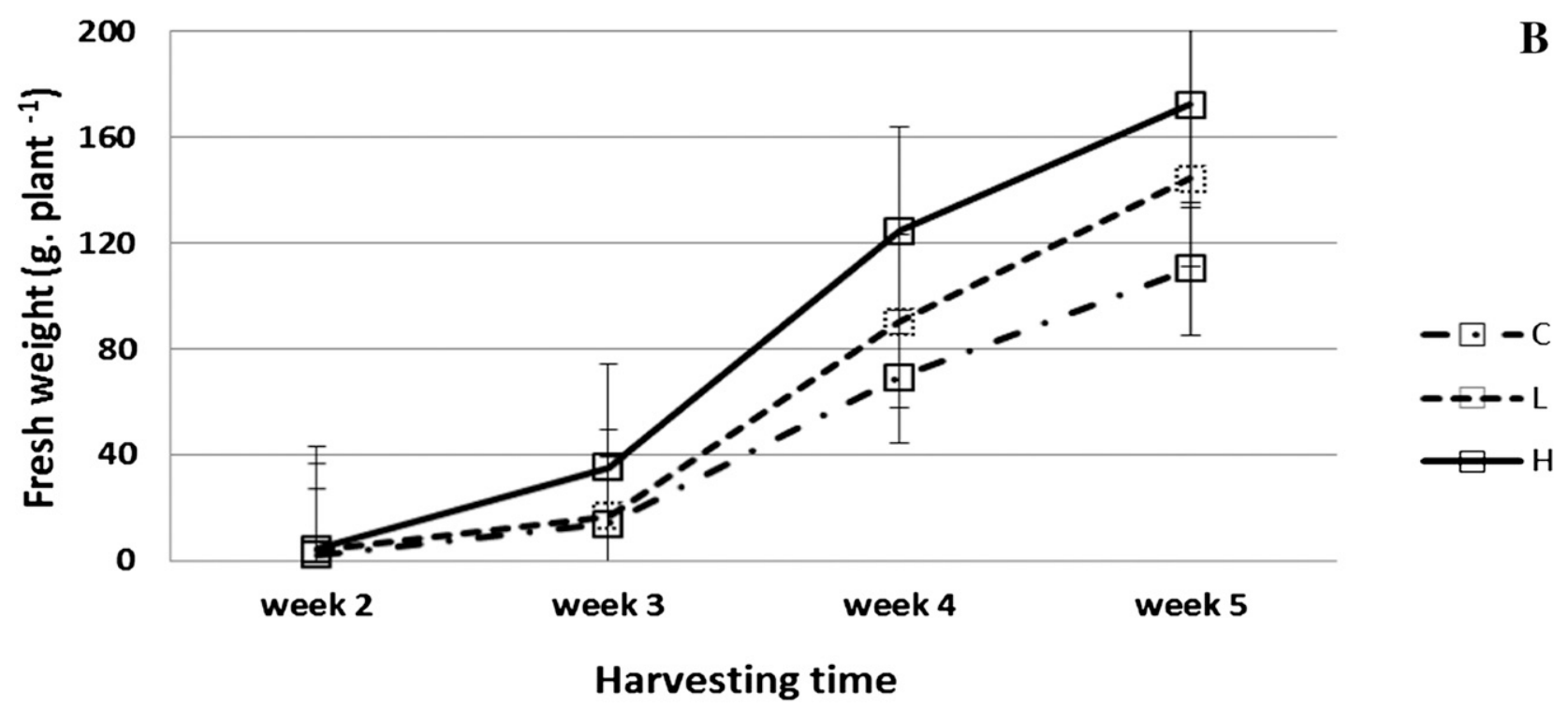

Fig. 11. Pac choi fresh weight (g/plant) during production period at high-tunnel organic $(\mathbf{A})$ and conventional (B) plots for different nitrogen $(\mathrm{N})$ fertility rate (control, low, and high) treatments. 


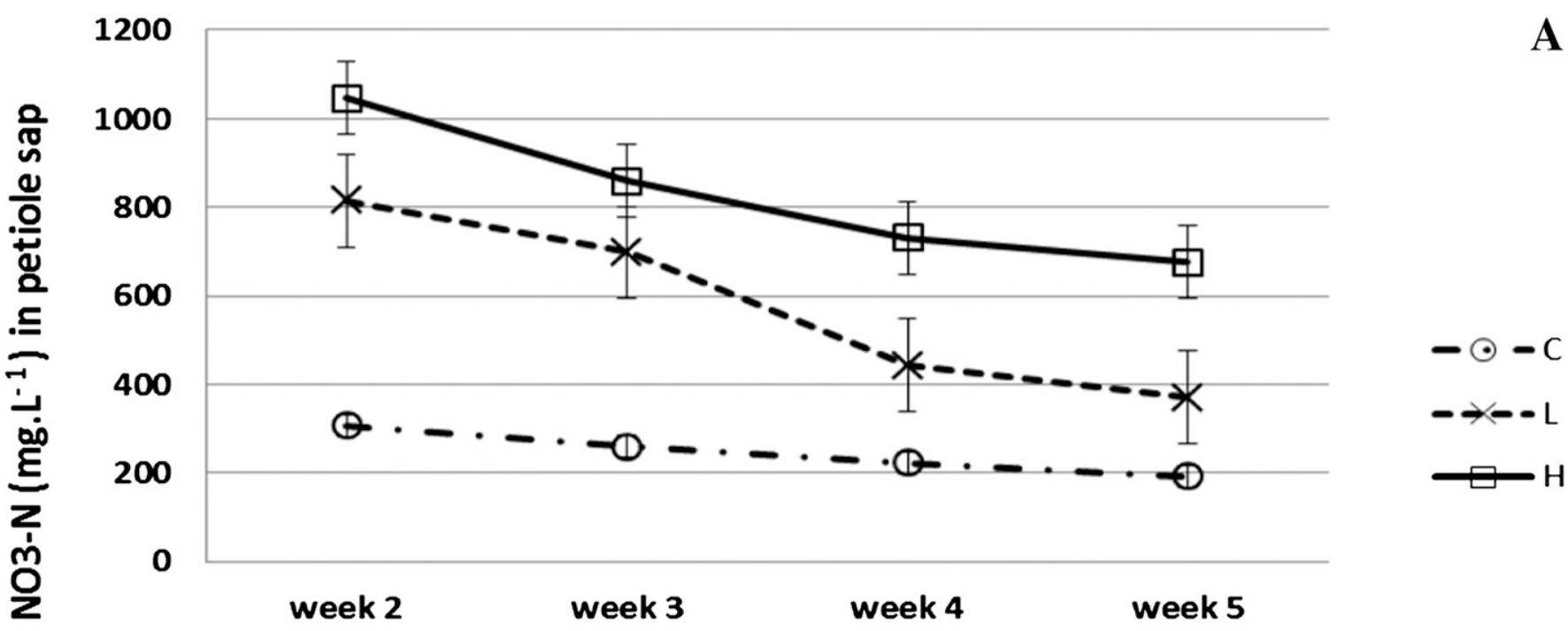

production period

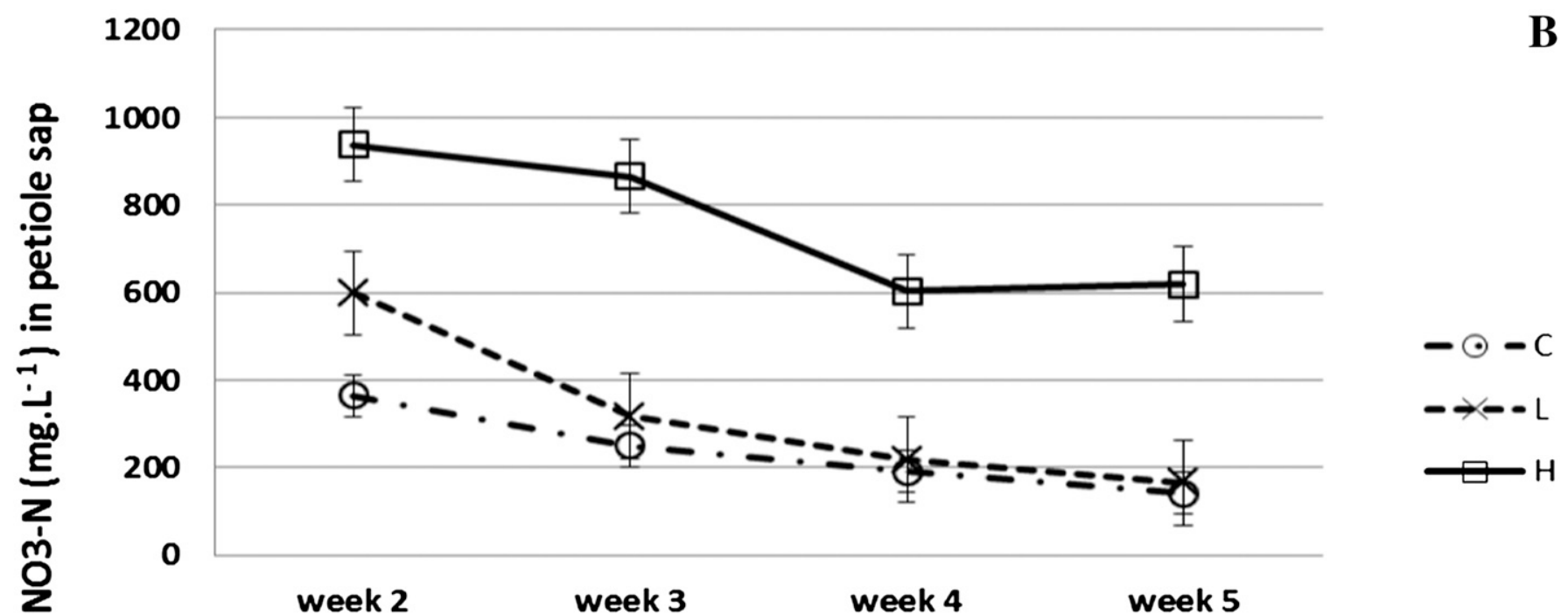

\section{production period}

Fig. 12. Pac choi petiole sap nitrate-nitrogen level $\left(\mathrm{mg} \cdot \mathrm{L}^{-1}\right)$ during the production period in field organic $(\mathbf{A})$ and conventional $(\mathbf{B})$ plots for different nitrogen $(\mathrm{N})$ fertility rate (control, low, and high) treatments. Fertility effect is significant at $\alpha=0.02$.

Table 4. Comparison of petiole sap nitrate-nitrogen (PSNN) for pac choi obtained from the greenhouse study, field and high tunnel, with published sufficiency ranges for comparable vegetable crops.

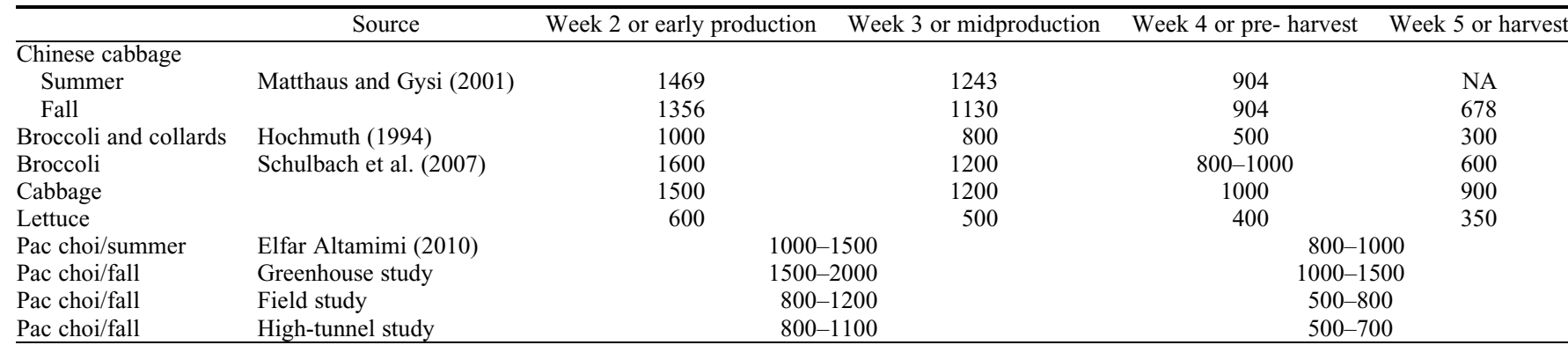

NA $=$ not applicable. 


\section{0}

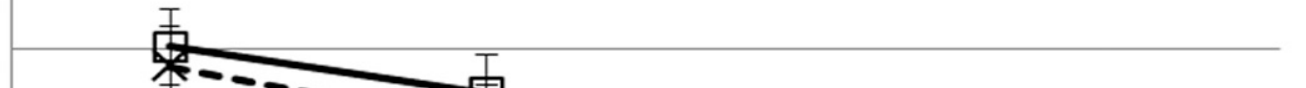

800

600

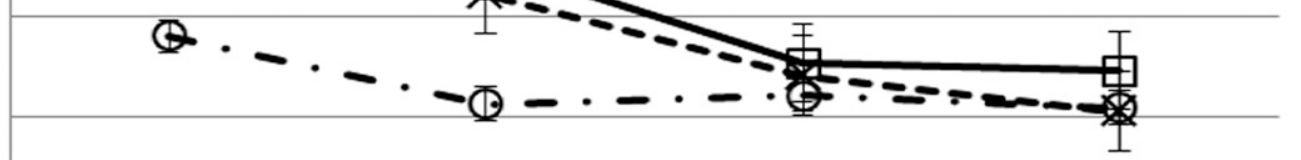

400

200
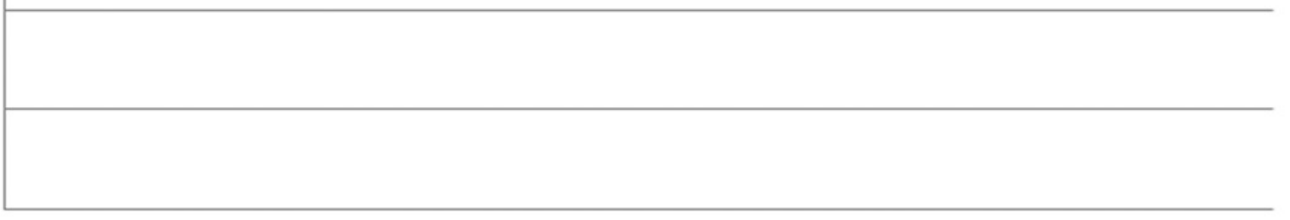

$\begin{array}{llll}\text { week } 2 & \text { week } 3 & \text { week } 4 & \text { week } 5\end{array}$

\section{production period}

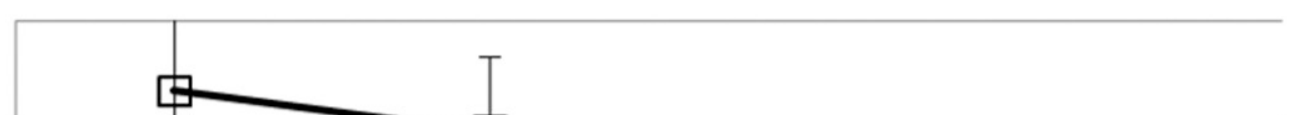

\section{0}

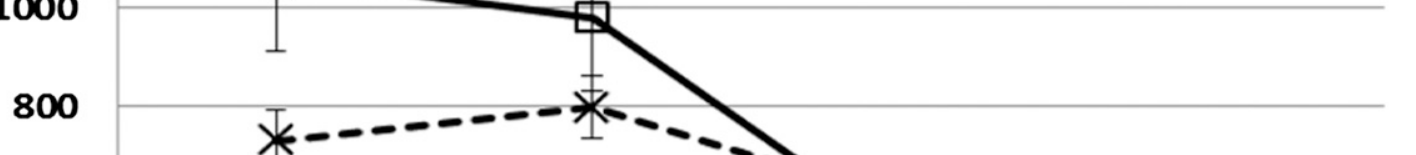

600

\section{400}

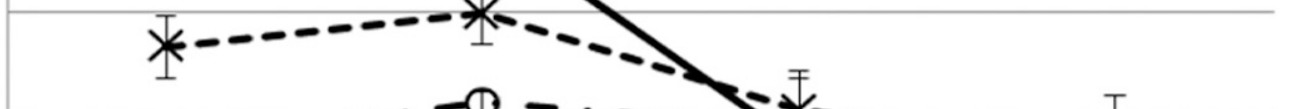

200

0

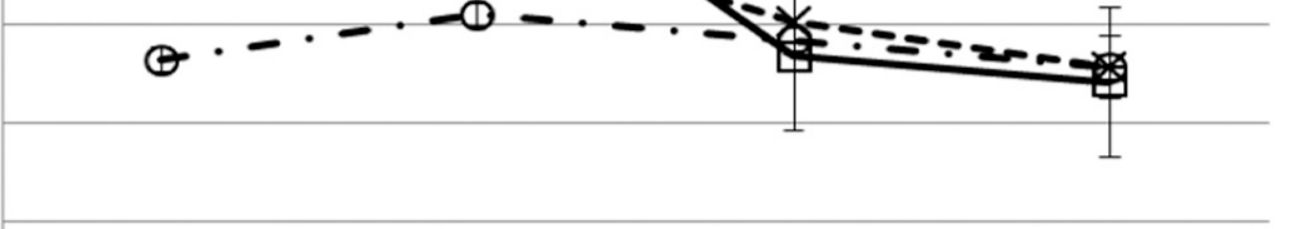

\section{production period}

Fig. 13. Pac choi petiole sap nitrate-nitrogen level $\left(\mathrm{mg} \cdot \mathrm{L}^{-1}\right)$ during production period in high-tunnel organic (A) and conventional (B) plots for different nitrogen (N) fertility rate (control, low, and high) treatments. Fertility effect is significant at Weeks 2 and 3.

\section{Literature Cited}

Albright, L. 2010. Pak choi handbook. Cornell University. Biological and environmental engineering. Sept. 2010. $<$ http://www.cornellcea.com/ Pakchoi_Handbook/pc_biological_significance. $\mathrm{htm}>$.

Amor, F.M. del, M.F. Espinosa, S. Molina, P. Varo, J.M. Camara, and Y.A. Lopez. 2006. Evaluation of methods for the determination of $\mathrm{N}$ in pepper crops. Horticultura, Revista de Industria, Distribucion y Socioeconomia Horticola 196:14-20.

Cantliffe, D.J. 1972. Nitrate accumulation in spinach grown under different light intensities. J. Amer. Soc. Hort. Sci. 97:152-154.

Cavins, T.J., B.E. Whipker, and W.C. Fonteno. 2008. Pourthru: A method for monitoring nutrition in the greenhouse. Acta Hort. (ISHS) (779):289.

Drews, M. and S. Fischer. 1992. Standards for nitrate and potassium in press sap analysis of greenhouse tomatoes and cucumbers. Gartenbauwissenschaft 57:145-150.

Elfar Altamimi, M. 2010. Nitrate-nitrogen sufficiency ranges in leaf petiole sap of pac choi grown with organic and conventional fertilizers. Master of Science, Kansas State University, KS.

Evans, L. 2006. Salinity tolerance in irrigated crops. Sept. 2010.<http://www.dpi.nsw.gov.au/agriculture/ resources/soils/salinity/crops/tolerance-irrigated $>$.

Gardner, B.R. 1989a. Midrib nitrate concentration as a means for determining nitrogen needs of cabbage. Marcel Dekker, New York, NY.

Gardner, B.R. 1989b. Midrib nitrate concentration as a means for determining nitrogen needs of broccoli. Marcel Dekker, New York, NY.

Gardner, B.R. and W.D. Pew. 1972. Response of fall grown head lettuce to nitrogen fertilization. Univ. Arizona Tech. Bul. 199.
Hartz, T.K., P.R. Johnstone, and E.S. Williams. 2007. Establishing lettuce leaf nutrient optimum ranges through DRIS analysis. The Society, Alexandria, VA..

Hochmuth, G.J. 1994. Efficiency ranges for nitrate-nitrogen and potassium for vegetable petiole sap quick tests. HortTechnology 4: 218-222.

Hochmuth, G.J., Maynard, D., Vavrina, C., \& Hanlon, E. 1991. Plant tissue analysis and interpretation for vegetable crops in Florida (No. SS-VEC-42). Univ. Florida Special Publication. Knewtson, J.S. 2008. Studies in vegetables and high tunnel production on the central great plains. Doctor of Philosophy, Kansas State University, KS.

Lyons, D.J., G.E. Rayment, P.E. Nobbs, and L.E. McCallum. 1994. Nitrate and nitrite in fresh vegetables from Queensland. J. Sci. Food Agr. 64:279. 
Marr, C.W., F.D. Morrison, and D.A. Whitney. 1998. Fertilizing gardens in Kansas. MF-2320. Kansas State University Agricultural Experiment Station and Cooperative Extension Service.

Matthaus, D. and C. Gysi. 2001. Plant-sap analysis in vegetables - A tool to decide on nitrogen top dressing. Acta Hort. (563):93-102.

Parks, S.E., D.O. Huett, L.C. Campbell, and L.J. Spohr. 2008. Nitrate and nitrite in Australian leafy vegetables. Aust. J. Agr. Res. 59:632-638.

Proietti, S., S. Moscatello, A. Leccese, G. Colla, and A. Ballistelli. 2004. The effect of growing spinach (spinacia oleracea L.) at two light intensities on the amounts of oxalate, ascorbate, and nitrate in their leaves. J. Hort. Sci. Biotechnol. 79:606.

Schulbach, K., R. Smith, T. Hartz, and L. Jackson. 2007. Guide to nitrogee quick-tests for vegetables with 'Cardy' nitrate meter (No. 95-0582). CDFA, CA.

Scuderi, D., F. Giuffrida, and G. Noto. 2009. Effects of nutrient solutoon EC on yield, quality and shelf-life of lettuce grown in floating system. Acta Hort. 807:221-226. (ISHS).

Talavera-Bianchi, M. 2009. Sensory alanlysis of pak choi and tomato grown under organic and conventional systems. Doctor of Philosophy, Kansas State University, KS.
Warman, P.R. and K.A. Havard. 1997. Yield, vitamin, and mineral contents of organically and conventionally grown carrots and cabbage. Agr. Ecosyst. Environ. 61:155-162.

Westerveld, S.M., A.W. McKeown, C.D. ScottDupree, and M.R. McDonald. 2004. Assessment of chlorophyll and nitrate meters as field-tissue nitrogen tests for cabbage, onions, and carrots. HortTechnology 14:179-188.

Wright, A.F. and J.S. Bailey. 2001. Organic carbon, total carbon, and total nitrogen determinations in soils of variable calcium carbonate contents using a Leco CN-2000 dry combustion analyzer. Commun. Soil Sci. Plant Anal. 32:3243. 